\title{
The Soundtrack of Social Movements among Kurdish Alevi Immigrant from Turkey in Germany
}

\author{
Ozan Aksoy ${ }^{1}$ \\ New York University, USA
}

\begin{abstract}
Based on multi-sited ethnographic research between 2010 and 2013, this article asserts that Kurdish and Alevi social movements in Turkey and in the transnational space have relied heavily on music and activist musicians to engage community members. This article marks several key songs, musicians, and events that effectively formed the soundtrack for these movements contributing the literature on cultural anthropology and ethnomusicology of protest movements as well as migration studies. Kurdish Alevi cultural entrepreneurs in Germany and Istanbul have established a transnational social field in which they can relate to members from those communities living in multiple locations. This multiplicity results from simultaneous politicization processes of Alevi and Kurdish movements that have allowed old and new actors to engage with political and social capital along with symbolic capital through cultural and religious activism around multiple identities. The transnational space has allowed new actors to employ different means to serve their main political goals: cultural, musical, and those of other art forms, along with public campaigns to mobilize activists. Therefore, cultural entrepreneurs and other religio-political actors have been navigating in this transnational space while reformulating their political demands.
\end{abstract}

Keywords: Kurdish Diaspora, Germany, Alevi, music, ethnography.

\section{Introduction}

I had many melodies in my head from my early childhood. Like "Medina Min," which I had on my last album, the melody I remember my grandmother used to sing; I added some parts and modernized it with a traditional touch. "Demme Demme" is another melody I remember from a Kurdish Alevi cem ceremony I attended when I was five years old. It was sung and performed by Seyit Murtaza, who was a rehber (guide) and also mirtik (entertainer), in a big house in our village. I also recorded my mother's version of the dance of that semah a couple of decades ago. Our holy book is this three-stringed lute [bağlama], which goes back all the way to Zarathustra. Its melody allows human spirits to rest. The dance makes the body connect with the soul. (Ali Baran, personal communication in 2011).

Ali Baran, whom I interviewed in Germany and New York in 2011 and 2012, is an exiled singer in Germany touching on many of these elements in the above quote where he explained what the sources of his music and lyrics are. Son of the great late Mahmut Baran, he has engaged with both Kurdish and Alevi repertoires since his early childhood years. Baran's quest to represent traditional forms of Kurdish Alevi music has resulted in a diverse set of compositional approaches. Along with original lyrics, he has composed music for poems written by famous Kurdish poets such as Cigerxwin, Feqiye Teyra, and Mela Ciziri. Prominent Turkish and Kurdish musicians have covered many of his compositions. Our conversation ended with talk of the passing of Aşı Mahsuni, probably the most prolific Alevi aşı or ozan (bard) of modern times. Baran told me that although he used to criticize Aşık Mahsuni, now that he has passed away no other Turkish and Alevi folk music composer can fill the void. Baran described elderly musicians like himself as "like apples fallen to the ground, waiting to go bad." Ali Baran's music has influenced Kurdish Alevi musicians who have claimed both Kurdish and Alevi identities to various degrees. His primary audience has been of Kurdish Alevis, though he had many followers among other Kurds and Alevis in Germany and Turkey. Embodied in

\footnotetext{
${ }^{1}$ Correspondence; School of Professional Studies, New York University, 7 East $12^{\text {th }}$ Street New York, NY. E-mail: oea2@ nyu.edu
} 
the lives of diaspora musicians like Ali Baran, Kurdish Alevi social life cannot be defined without reference to music and oral tradition, especially the saz or bağlama (also known as tembûr in Kurdish), a long-necked lute that holds special symbolic significance for the Kurdish Alevi people.

Music mediates the identities, homelands, and their activism. The sound of the bağlama or tembutr defines Kurdish Alevi social life, further this long-necked lute has gradually crowned as an essential symbol of the Kurdish Alevi people over the years. Each generation of Alevi men teaches this instrument to their sons; and it is part of the masculinist project of passing down politics and the symbols of identity from father to son (Thangaraj, 2015). For Alevi families, especially for Kurdish Alevis, family socialization with music is a central element of community cohesion. In the process, music also serves in both affirming community and serving as a vehicle of protest (Abe, 2016; Manabe, 2015).

Who are the Kurdish Alevis? Since no official census figures account for Kurdish or Alevi people in either Turkey or Germany, it is difficult to pinpoint the size of this population. According to widely accepted estimates, around fifteen million Kurds are living in Turkey and 700,000 in Germany, of whom the majority are Sunni Muslims, while approximately one third are Alevi (Aksoy, 2014). On the other hand, varying estimates place the total population of Alevis in Turkey at around twenty-five million, of whom a quarter (slightly over six million) are Kurdish while the remaining nineteen million are of Turkish, Arab, or Albanian (who are Bektaşi) origin. I use the term Alevi, like almost all that call themselves such, to include the people categorized under the larger Alevi-Bektaşi tent that has been used to label all heterodox groups in Anatolia in the twentieth century (Dressler, 2013). In the current public discourse in Turkey and elsewhere, Alevis and Bektaşis use the labels Alevi and Alevi-Bektaşi interchangeably to refer to all of those heterodox groups. The Turkish-speaking Alevi groups include the Tahtacı, Çepni (see Gökalp 1980 for a more detailed account), and Abdal, whereas the Kurdish-speaking Alevis include both Kurmancî and Zazakî speakers, some of whom identify themselves as Kızılbaş.

Alevism (Alevilik, Elewî, and Kızılbaş) is an Anatolian religion whose relations to both Sunni and Shi'a Islam are historically controversial. Markus Dressler defines Alevis as "a number of heterogeneous socio-religious communities in Turkey and the Balkans, historically referred to as Kızılbaş, who in the twentieth century began to share in a common trans-regional Alevi identity called Alevism" (2008, p. 93). Turkish Alevis, mainly from Central and Eastern Anatolia, constitute the majority of Alevis in Turkey. A quarter of Alevis are ethnic Kurds speaking Kurmancî or Zazakî (Dimilî). Kurmancî is the most commonly spoken Kurdish language/dialect among some thirty million Kurds in the world, the majority of whom live within the borders of Turkey. Most Kurmancî speakers are Sunni Muslim while a small minority (approximately 20\%) are Alevi. Zazakî is the language, sometimes categorized as one of the dialects of Kurdish by Kurdish nationalists, spoken by the residents of cities in Turkish Kurdistan ${ }^{2}$ including Tunceli, Elazı ğ, and Diyarbakır. More than half of Zazakî speakers are Alevi though not all of these identify as Kurds (Kaya, 2011). Thomas Solomon (2011), in discussing the diversity of the immigrant population from Turkey in Germany, refers to the situation as the "dizzying array of multiple identities" among the broader "Turkish community."

\section{Methodology and Complexities of Kurdish Alevi Self-identification and Ascription}

Taking the approach of Martin Stokes (2010) in his work on music in Turkey, I rely on a particular set of representations - in this article cornerstone or iconic songs and their representations through radio, TV, and Internet broadcasts - explored as texts. These musical examples, as specific musical "objects," mediate multiple and sometimes contradicting identities through sonic, social, discursive, and visual modes. My access to musicians was helped by the fact that I am a member of this community and a former member of a popular music group whose music has found a loyal following among Kurdish Alevis interviewed for this transnational project whereby Kurdish identities and social movements cannot be understood as territorially bound.

For this study, I participated in cultural events sponsored by various organizations that provide an arena for Kurdish and Alevi sociability and socio-political outreach and organizing. Each city and different national site present varying relations to Kurdistan and Kurdish life. Germany is the country with the largest Turkish immigrant population in Europe, hosting about 70 percent of all Turkish immigrants, and Cologne hosts the second-largest immigrant population in the country. Almost half of those immigrants are from Turkey, with a sizeable Kurdish segment (Sirkeci, 2006). At the same time, Cologne has been a leading center for Kurdish and especially Alevi social and political organizations in Germany. The headquarters of many associations such as KOMKAR (Immigrant Organization of the Kurdistan Socialist Party), FEK (Federation of Kurdish Alevi Associations), and AABF (Federation of Alevi Unions of Germany) are located in Cologne. The founders of those cultural, political, and religious centers have also chosen

\footnotetext{
2 Although Kurdistan has been known for centuries as the geographical location populated mostly by Kurds (along with Turkmens and Arabs among others), it is still a politically charged label and term in Turkey.
} 
Cologne as their base. I researched Internet forums and forms of digital sharing platforms, including social media sites like Facebook and YouTube (Mahmod, 2016).

I conducted over 80 interviews of Kurdish Alevi immigrants and refugees in Cologne and Istanbul. Those Kurdish Alevis trace their roots to villages within a geographical triangle defined by the eastern Turkish cities of Maraş, Malatya, and Adıyaman. What makes this group of Kurdish Alevis a unique anthropological subject is that among all ethno-religious groups in Turkey, only the Kurdish Alevi communities have followers of both Kurdish and Alevi political movements. The Alevi awakening movement of the 1990s and the Kurdish uprisings of the 1980s and 1990s have posed among the most severe challenges to the hegemonic cultural, legal, and economic policies of the Turkish state in the last three decades. Kurdish Alevis have become involved with both of these challenging and contradictory movements.

\section{Migration History of Kurdish Alevis in Turkey and Germany}

As part of the 1960s guestworker wave from Turkey, many Kurdish Alevis settled in Germany constituting the initial group of immigrants (Ammann, 2001). Then came the second wave of more politically organized members of communities, creating a wave of refugees and asylum seekers. Hometown associations and cultural centers, including Alevi centers, have been providing job placement workshops, vocational training, and other supportive activities for community members. Since the stigma about the immigrants among Germans has been that those immigrants have been "sucking up" federal welfare funds instead of working at jobs to support their families, most Alevi and Kurdish organizations have been working to improve the employment conditions of their community members. Kurdish Alevis own or run diners, cafes, restaurants, bars, and mobile phone shops, while some have highpaying jobs at private companies or governmental institutions. Some Kurdish Alevi women also own or manage businesses, like Meryem, who helped for this study tremendously and is managing a türkü bar and a restaurant.

Kurdish Alevis have settled in cities such as Hamburg, Berlin, Stuttgart, and Cologne, where they have relied on established family networks. As Martin Sökefeld documents in his outstanding work on Alevis, the first Alevi organization was established in Hamburg and more followed suit (Sökefeld, 2008). The Kurdish Alevis I studied have set up enclaves in the Cologne area such as those in Bergisch Gladbach, downtown Cologne, Wuppertal, and Essen. The scope of this study was limited to the Kurdish Alevis living in or near Cologne in order to narrow the sample to get a cohesive picture of their music. The presence of all Alevi and Kurdish organizations in Cologne provided a full picture more accurate than in any other location in Germany.

In their first homeland, where state authorities denied their social and cultural identifications, this double minority group, mobilized transnationally, has proved itself to be in opposition to the Sunni Muslim Turkish majority at all levels. Members of this group have conflicting and contradictory ideas, practices, and identities regarding themselves and their fellow Kurdish Alevis. There has been a constant political and cultural suppression by the Turkish state over the Kurdish language and culture. Since Kurds have lacked institutional support of their state, they have coalesced around various imagined communities that were policed by the states ruling them such as Turkey, Iraq, Syria, and Iran. Kurds, in turn, relied heavily on the oral tradition to maintain networks and historical ties with their fellow Kurds dispersed around the world. Some Kurdish speaking Alevis who have already embraced Turkish identity as their primary identity marker may refuse all other labels. Some Kurdish speaking Alevis may not believe in any religion. In claims-making processes of Kurds or Alevis, those who are both Alevi and Kurd, both in Germany and Turkey, might invoke a multiplicity of self-identification.

Being Kurdish Alevi cannot be isolated within one set of national borders. While Kurdish Alevis in Germany enjoy greater religious freedom than their relatives have done in Turkey, they nevertheless face unique struggles of their own as they are relegated to what I refer to as a "dual minority status" (Kurdish and Alevi). More specifically, in Germany, Kurdish Alevis are vulnerable to the same kinds of discrimination that they experience in Turkey in their encounters with the Turkish Sunni immigrants who constitute the overwhelming majority of the immigrant population in Germany. The Turkish state and its legal apparatus, which subsumes differences among its citizens beneath the blanket categories of "Muslim" or "Turk," deny Kurdish Alevis' distinct Alevi religious and Kurdish ethnic modes of belonging. Kurdish Alevis in Germany find themselves part of two minority populations, by virtue of both their Turkish background and their difference from "other Turks." The populations of Kurdish Alevis have faced the racialization and longer histories of colonialism with their Turkish counterparts while negotiating and managing their marginalization in larger German society with German specific realms of racial stratification.

\section{The Soundtrack of Social Movements among Kurdish Alevis}

Musical practices and discourses express specific stances, ideas, messages, and emotions. Music can either help or prevent people from listening to what others say and feel. It can alleviate pain and suffering; it can heal. Musical 
practices and discourses can also convey hatred, exclusion, and violence (Aksoy, 2014). Musicians might also help initiate peace as articulated in discourse outside of the boundaries of official claims. Musical expression includes lyrical discourses as well as sonic, aesthetic, and symbolic messages that musicians bring together. The relationship between music and social movements, and social networks in various communities has received ample attention in recent ethnomusicological and anthropological studies (Hirschkind, 2006; Sugarman, 1999). Among many scholars, Sugarman and Hirschkind argue that music has a unique and indispensable role in articulating the demands of community members. In his Ethical Soundscapes, Hirschkind highlights the significance of the sermons of Muslim clerics recorded on cassettes in the dissemination of conservative ideologies within one of the counter-publics of Islam in Egypt (Tolba, 2018). Other ethnomusicological studies have dealt with the functions of circulating music among immigrants in the formation and maintenance of a variety of national, ethnic, and religious identities and social networks (Hyder, 2004). Recent studies on the reconciliation efforts of musicians within the disciplines of cultural anthropology and ethnomusicology have explored the ways music functions in and contributes to cultural reconciliation processes and formations of cohorts among immigrants, in both majority and minority communities (Laurence \& Urbain, 2011, O’Connell \& Castelo-Branco, 2010). Both collections are welcome additions to the process of understanding music and conflict, and the transformation as well as fomenting of conflict through music-making. The authors demonstrate the significance of music in both reinforcing disputes and conflict-resolution efforts in situations ranging from the Catholic-Protestant dispute in Northern Ireland to the enactments of conflicts between African American and Euro-American musicians.

Others have examined the role of music in peace-building and the reconciliation efforts in conflicts in South Africa, the Americas, and in the Arab-Israeli conflict (Urbain, 2008). On the subject of the Arab-Israeli conflict and musical reconciliation, Brinner, for example, argues that the efforts of musicians on both sides of the conflict contributed significantly to the emergence and sustenance of common cultural ground (Brinner, 2009). In that regard, reconciliation attempts through music in the Turkish and Kurdish dispute show commonalities with other disputes like the Palestinian-Israeli conflict that Brinner discusses. In the case of Turkish and Kurdish communities, music and musicians have reenacted peace both on stage and on their albums in order to counter the othering of the Kurds in Turkey that occurs in both the political and cultural spheres (Mackey, 1993). The peace might be rehearsed and staged via representing others as the perceived 'us' (Turks, Kurds, and others) in order to create a platform engaging all distinct socio-cultural entities constituting the multi-ethnic fabric of Turkey.

The new music embraced the immigration issues that fellow immigrants and refugees faced. Many musicians I interviewed began performing not only in Germany but also in Turkey benefiting from the opportunities in both countries while navigating the political and aesthetic space they created in both homelands. In the summer, these musicians give concerts in places where immigrants might spend a few weeks, either their hometowns or near vacation spots on the west coast of Turkey. Discussions on music in the diaspora provide insight to understand the contact zones (Clifford, 1997) that diasporic communities inhabit. James Clifford (1997) emphasized the agency of individuals and the role of diasporic consciousness, drawing attention to the formation and reformation of diasporas through a constant renegotiation of their borders by persons choosing how they will associate themselves with others. For Clifford, diasporas are not static bodies, but rather a mode of consciousness marked by ethnic or religious boundaries.

Similarly, Martin Sökefeld (2008), who has studied Alevi communities in Germany, has suggested an understanding of diaspora as the creation of an "imagined transnational community." Building on the diaspora studies scholarship, Sökefeld rightly argues that speaking of an "Alevi diaspora negates the idea of [national] homogeneity... and Alevi diasporic associations endorse multiple identifications" (2008, p. 252).

The close relationship between music/sound and social movements and social networks in various communities has received ample attention in recent ethnomusicological, sociological, and anthropological studies (Fitzgerald, 2019; Hirschkind, 2006; Sugarman, 1999). Many scholars have argued that music has a unique and indispensable role in articulating the demands of community members. Recent ethnomusicological studies have come to focus more on the power, politics, and musical expression among immigrants and minorities (Bohlman, 2004; Nooshin, 2009; and Turino, 2008). Drawing on ethnomusicological studies of the relationships between music/musicians and political and social movements, I believe that music has been a crucial part of both the sociocultural and the political milieux. Other ethnomusicological studies have dealt with the functions of circulating music among immigrants in the formation and maintenance of a variety of national, ethnic, and religious identities and social networks (Hyder, 2004; Meintjes, 2003; Shannon, 2006).

Music and dance can foster engagement between peoples at concerts or political rallies. Dance has become an indispensable part of the protest tradition. Among many festivals and events that I have attended, as a performer on stage or as audience participant, the most exciting and anticipated part centers around the dance. At various kinds of political rallies for organizations associated with Turkish, Kurdish, and Alevi groups I have found it difficult to resist joining in, feeling the collective teeming and waving bodies of Kurdish and Turkish youth altogether. In dance, the engagement between individual bodies and with the collective kinesthetic whole is expressed in the line-dance (govend 
in Kurdish, halay in Turkish). At protests, Kurdish and Turkish activists and onlookers join in govend while shouting certain slogans in unison. They dance hand-in-hand in the same rhythm with complex foot movements, which are reminders of a shared expressive history. More than just a traditional line-dance, the govend becomes a tool to discipline the bodies and create a unified collective. Fast-paced and traditional wedding types of music and commonly known folk songs with regular rhythms dominate the repertoire. In political rallies, the govend represents the appropriation of a traditional dance into the demonstration, supporting the political cause of the organizations involved, a phenomenon that resembles the common practice of dabkeh (a line dance among Arabs in the Levant) by Palestinian refugees in Jordan (McDonald, 2010). In both the Kurdish and Palestinian gatherings, group dancing works alongside other discursive forms of struggle (speeches, for example) to reinforce and reproduce collectivity among people to coalesce around common political causes. In these two contexts, collective dance with responsive singing, like other genres in the world, can be interpreted as creating a new habitus as a bodily inscribed practice that breaks away from the verbal discourse, as a bodily inscribed communal action, and eventually as a group cohesion-building process. This practice also improves the bonds among Turkish and Kurdish audiences from different backgrounds who come to the concerts and events organized by peace-seeking musicians and artists. It provides space where bodies move together and hold each other, as even another form of reenacting peace, harmony, and synchronization.

Music can provide a sonic and kinetic space to help enhance bonds between people of varying backgrounds, identities, memories, and traumas. Music can also enhance cultural understanding between peoples who have systematically been indoctrinated to misunderstand each other and can create a sense of a common cultural tradition and historical bonds shared by Turks and Kurds in Turkey for centuries. As the Kemalist modernity project as the foundation for the new Republic took off, especially during the Cold War period, it was common to encounter Marxist and other leftist movements being embraced by secular youth of all denominations, but especially Kurdish Alevis (Ertan, 2008).

\section{a. Anti-Imperialist Soundtrack}

An essential figure in the folk and protest music scene in the 1960s and 70s Turkey was the great Aş1k (bard singing folk poetry) Mahsuni. Mahsuni composed more than 5000 songs on his bağlama before his death in Cologne in 2002. He was a popular figure, especially among Kurdish Alevis of the older generation, and my parents still admire his work. As a member of the leftist anti-imperialist movement, Mahsuni objected to American influence in the conservative and right-wing government policies of Turkey; in 1976 he wrote the song "Amerika Katil Katil” (America the murderer), which became very popular among the Kurdish Alevis at the height of this period. Kurdish Alevis have listened and sung along with Aşı1k Mahsuni's songs during their exodus from their homeland.

\section{Example 1: “Amerika Katil Katil” (America the murderer), by Aşık Mahsuni, 19763}

Defol git benim yurdumdan

Amerika katil katil

Yillardır bizi bitirdin

Amerika katil katil
Get the hell out of my country

America the murderer

You consumed us for years

America the murderer

As an example of the soundtrack of the social movements in the 1970s, this popular song has become the epitome of the anti-American and anti-imperialist discourse among Kurdish Alevis along with other leftists in the country. Among the Kurdish Alevis I talked to for this study, America was seen the culprit of keeping the undemocratic regime in Turkey and responsible for the civil war inside the country.

In the cosmopolitan settings of such cities, and through encounters with other Turkish inhabitants, "the music they listen to, the books they read, the way they talk, and the food they eat all are different from the first homeland counterparts," said Kadir Abi, an elderly restaurant owner in Cologne. "While their parents and grandparents used to hold hidden cem (religious gatherings) in the memleket (homeland), those ceremonies have almost vanished in the second since the new generation started to believe in different ideals, such as the revolution," observed Şevki Abi, who

${ }^{3}$ https://www.youtube.com/watch?v=t0c9jxO0gnI 
is in charge of religious affairs at the Wuppertal Alevi Culture Center. As much as they have stopped believing in or practicing the Alevi religion (signaling a rise in atheism), for many Kurdish Alevis, Alevi identity has become a badge of honor to defend against others who would disseminate lies of incest and orgies to denigrate Alevis, via phrases like "Alevis do mum söndü," "candle extinguishing," which historically has been one of the smears used to demonize Alevis among Sunnis in Turkey.

In the years preceding and following the third military coup d'état of September 12, 1980 in Turkey, possession of audiocassette tapes by Şivan Perwer, who sang proletariat marches in Kurdish, or Aşık Mahsuni, Aşık Nurşani and Aşık Ihsani, who sang türküs (the generic term for folk tunes) along with other calls for solidarity, were deemed grounds for the arrest for Kurdish Alevis who had bootlegged the albums. The 1980 military coup demonstrated definitively how the Turkish state exerted its power over dissenters by arresting almost every adult who had anything to do with politics, and by torturing and killing thousands of innocent people (Ayata, 2011; Zürcher, 2004). The coup marked the limits of the freedoms granted by the state, which reclaimed hegemonic power over its citizens.

\section{b. International Revolutionary Songs}

Gradually Kurdish Alevis went even further, to Europe, to pursue a safer and better life. As mentioned earlier, the first wave of Kurdish Alevis to settle in Germany (along with other guest workers from Turkey) began arriving in the early 1960s. As migrant laborers, they worked in harsh conditions with low pay. The environment of insecurity in Turkey caused a second major wave of politically active Kurdish Alevis arriving Germany as refugees and asylum seekers. Recording voices and music on cassette tapes and mailing them to family members in Germany maintained ties and made possible the retention of the sonic environment of the first homeland. These cassettes gradually replaced long letters, which posed problems, especially for the illiterate elderly. One of the iconic songs of this period, a proletarian march, was the Turkish version of the "Austrian Workers' March," otherwise known as "Hayat Denilen Kavgaya Girdik" ("We Joined the Fight Called Life"). Fervent Kurdish Alevi activists in Germany sang this song on every possible occasion as part of the remembrance of shared revolutionary values. "Singing certain marches together must have sealed certain initiation ceremonies within a leftist group," said one of my elderly informants. Individual marches were associated with specific political groups. Later, Group Yorum, Ahmet Kaya, and Ferhat Tunç became popular among the Kurdish Alevi youth.

\section{Example 2: "Hayat Denilen Kavgaya Girdik," ("We Joined the Fight Called Life").by Group Kızllurmak (Red River), $1991^{4}$}

We joined the fight called life

Walking with steel steps

We see the sun

Approaching after this darkness

Passing mountains, it is getting closer

Polaris, the bird of winning

This is not a dream,

But it is the star of the victory

“Austrian Worker's March" was later recorded by the group called Kızllırmak. The local police shut down one of the private radio stations, Özgür Radio, for four months after this song was played on the radio in 2000. In this period, the leftist movements swayed Alevis in Turkey towards denying their religion in favor of socialism or communism.

\section{c. Alevi Awakening and Songs after Sivas Massacre}

\footnotetext{
${ }^{4}$ https://www.youtube.com/watch?v=6b6rE7wpZ5Y
} 
In villages, large living rooms became focal points for listening to radio broadcasts in order to hear news and music from stations including Turkish Radio Television, Radio Yerevan, and Radio Baghdad, along with the BBC. The Alevi repertoire has become part of singing in public for financial or other benefits and has survived in gatherings in which alcohol is consumed as well. Thus, the music has become decontextualized from its Alevi ethos. Kurdish Alevi musicians historically provided resources for the Alevi repertoire that famous folk musicians like Arif Sağ utilized and later popularized. Of great importance to any discussion of cultural hybridity, integration, and assimilation is the strong presence of Turkish words and phrases in the Kurdish oral literature of Kurdish Alevis living close to Turkish communities in Maraş, Malatya, and Adıyaman. The inclusion of Turkish words and phrases in the KurmancîKurdish of this region is not merely a strategy of survival for this unique culture. Bilingual Kurdish and Turkish songs have been overlooked not only by Turkish cultural policymakers but also by Kurdish purists since this group exhibited signs of "assimilation" more than other Kurdish communities did. To that end, the music of the Kurdish Alevis exhibits multi-vocality and multi-locality of both Kurdish and Alevi identities while refusing the notions of equivalence (Hong, 2006 Lowe, 2007). Turks have embraced many Turkish and bilingual songs from this repertoire. Alevi and türkü tunes that made their way towards the Turkish folk music milieu created liminal spaces that helped many to navigate in between multiple homes and homelands.

Like all Alevis in both homelands, Kurdish Alevis articulate the Sivas Massacre as the watershed moment for them to identify themselves as Alevi. The victims of this pogrom, most whom were famous Alevi musicians such as Hasret Gültekin, Nesimi Çimen, and Muhlis Akarsu, along with dancers, poets, scholars, and intellectuals, were in Sivas to attend a cultural/religious festival on July 3, 1993. The attendees were trapped inside a hotel called Madimak and mobs of Sunni residents and laypeople burned the hotel down. The massacre has made its way through the most indispensable moments of Alevi social memory (see Özyürek, 2001 for social memory in Turkey). Alevis embraced their Alevi identity after the massacre, which demarcated it as a political and organizational milestone. Because of the fact that it involved a music festival and many musicians were killed, music then has further functioned as a critical space to memorialize this event and organize as a community. Thus, a historical narrative filled with the atrocities committed against Alevis has been used to remind Alevis, especially Kurdish Alevis, never to trust the Turkish Sunni state, as almost all of the atrocities committed against Alevis targeted Kurdish Alevis in Maraş, Gazi, Malatya, and Sivas. As Kurds, Kurdish Alevis have been subjected to constant assimilation and forced migration policies by the Turkish state coupled with a constant denial of their ethnic and linguistic rights. Massacres and other forms of atrocities committed against Kurds and Alevis were used to create local heroes in Kurdish Alevi narratives, which have been transmitted from generation to generation. Kurmancî Alevis from Maraş and Malatya, for instance, have many heroic songs and laments written for Mehmet Ali, who was sentenced to death in 1915 after he allegedly helped Armenian fighters. In practice, the dominant Sunni Muslim jurisprudence in Turkey does not accept Alevism as a legitimate religious denomination, within Islam or separate from it (Dressler, 2013; Kaya, 2015).

Today, the commemorations of the anniversary of the massacre are among the most significant events that the Alevis I interviewed regularly attend in order to protest. Especially after this event, one could see a change in the tone of Alevi activism, which led to a change in hometown organization titles to include Alevi, Bektaşi, or other titles associated with Alevi religiosity. Almost identical with what the 1984 Sikh massacre in Punjab, located in the imagined Sikh homeland of "Khalistan," did to organize Sikhs around a unified objective (Axel, 2001); the Sivas Massacre was instrumental in unifying a political message for Alevis. The reaction was much stronger among Alevis in Germany than among those living in Turkey, which in a sense helped galvanize all Alevi organizations to mobilize, creating a transnational social field strategically locating Alevis, especially Kurdish Alevis, in opposition to the Turkish state (Aksoy, 2014).

\section{Example 3: “Türküler Yanmaz” (“Türkü cannot be burned”) by Edip Akbayram, 19945}

Güneşin ak yüzüne bir duman çöktü

Bir türkü çığlıkla ateşe düştü

Kuytu bir köşede bir çiçek küstü

Döktü yaprağını boynunu büktü

${ }^{5}$ https://www.youtube.com/watch?v=R0wZMPKgnsI
A smoke cloud fell down on the shining sun.

A türkü fell into the fire screaming

A small flower stopped smiling,

Left its leaves and let its neck loose 
Aksoy, O.

Şu Sivas'ın elinde sazım çalınmaz

Güllerim yandı yüreğim dayanmaz
They don't allow my bağlama played in Sivas

My roses were burned, my heart hurt

"Türküler Yanmaz" is a noteworthy rebuke of musicians to the massacre. It conveys the symbolic significance of the bağlama and the türkü, the folk song. The bağlama embodies Alevi history as part of the Alevi identity and it encapsulates the Alevi sonic memory. Thus, the bağlama is a crucial element of religious practice and the image Alevis have promulgated. The bağlama that was not allowed to be played in "Türküler Yanmaz" is a symbolic reference to the denial of the existence of Alevis. The song urges Alevis to remember that the mobs in Sivas wanted to kill the songs and burn the bağlamas.

The new transnational field has provided a space and means for cultural entrepreneurs and especially musicians to get involved with identity politics. One of the most significant cultural forms Kurdish Alevis and musicians relate to Kızılbaş identity and its history is "Kızılbaş music." Thus, Kurdish Alevi musicians I talked to, including Shêxo, Ali Baran, Mikail Aslan, and Hakan Akay, return to the descendants of common ancestors, those living in Iran. By embracing the music of the Ahl-e Haqq of Iran, and relating to religious or secular music of other heterodox groups in West Asia, those Kurdish Alevi musicians are trying to resuscitate a mode of belonging, even as they have no real living example they might relate to in their first homeland.

\section{d. Kurdish Movement and Its Soundtrack}

The conflict between the Turkish state and the alleged Kurdish "separatists" shaped many Kurdish Alevi musicians' understanding of ethnic belonging and pressed them to side with the Kurdish nationalist movement in the early 1990s. This process is manifested in the songs that they have written, performed, and disseminated from the late 1990s through today. It is also significant to talk about the "Kurdish Question" of Turkey in this context since it has shaped the political loyalties of Kurdish Alevi musicians and the cultural production of their music.

Along with the Kurdish political activism, the idea of martyrdom continues to dominate Alevi and Kurdish personal and collective narratives, reproduced as part of the Alevi imaginary of suffering for centuries under Sunni rule, from the Ottoman Sultan Selim II through the Sivas massacre in 1992 and the Gazi events in Istanbul 1995, in which Alevis were killed by state troopers along with Sunni rioters (Bayrak, 2011; Dressler, 2013; van Bruinessen, 1997). After the Sivas events, Alevi musicians composed multiple songs to commemorate and to reflect on the burning of the musicians. Below is the most popular among those performed by my informants; it was requested multiple times at the türkü bars I visited in Germany.

The language in which a song is performed, regardless of its content, often becomes a more prominent marker than non-textual musical features differentiating it from other songs in other languages. In the 1990s, performing a song in a language other than Turkish constituted a political act. Performing in a language banned for decades deployed a counter-discourse to the official "separatist" discourse promulgated by Turkish nationalist power centers that continued to consider public use of the Kurdish language and music sung in Kurdish as separatist or terrorist acts. Ali Baran, in this album preceding the Sivas massacre and the Alevi revival, expressed the idea that Kurdish ethnic and national identity with the goal of Kurdish independence was the most significant mode of belonging for all Kurds, asking Kurds to join the ranks of the Kurdish movement in one way or another. The album and especially the title song are significant examples of Kurdish nationalist and to some extent militant calls made by Kurdish musicians. In "Êy Dêrsimê" Baran calls for all Kurds to unite through deferring all internal disputes, political differences, and historical problems.

\section{Ey Dêrsimê $\hat{e}^{6}$}

Êy Dêrsimê, êy Dêrsimê

Çi halê me heya niha

Dujminê me, bavkujê me
Hey Dêrsim, Hey Dêrsim

How do you do?

Our enemies who killed our ancestors

\footnotetext{
${ }^{6}$ The YouTube link for "Êy Dêrsimê:" http://www.youtube.com/watch?v=BWLFhM-f3Ms
} 


\section{Runiştîye mala me da \\ Em kar dikin, xebat dikin \\ Tiştek tune mala me da \\ Êy Dêrsimê, êy Dêrsimê! \\ Êy Dêrsimê, êy Dêrsimê \\ Çi rewş e ew heya niha}

Zêr zane û zor zane

Devê Tifinga mor zane

Her bêje gel, em şer dikin

Bo Kurdistan me can fîda

Êy Dêrsimê ,êy Dêrsimê
Are occupying out houses.

We labor tirelessly

Yet we are left hungry

Hey Dêrsim, Hey Dêrsim

Hey Dêrsim, Hey Dêrsim

How are you doing nowadays?

We now the yellow (gold) and the hardship

And the front side of the rifle.

Bless our people, we are going to struggle

For Kurdistan, our lives worth sacrificing.

Hey Dêrsim, Hey Dêrsim

In the lyrics of Êy Dêrsimê, Baran has a clear agenda of reporting the issues that Kurds, mainly those Alevi Kurds of the Dersim region, have faced. He calls Kurds to use all tools available against their enemies, which he does not mention by name. In the end, he calls for Kurds to join the fight and salutes those Kurds who could sacrifice their lives for Kurdistan, an apparent nationalistic reference making it illegal for the song and album to be circulated in Turkey until the 2000s. Although Baran had not continually emphasized Kurdish identity and was less militant than some of his peers, the lyrics of "Êy Dêrsimê" are perfect examples of a pan-Kurdish political and musical stance. Although some Kurdish Alevi musicians have occasionally resorted to militant and politically salient music, they inherently may have felt themselves to play the role of arbitrators or mediators between Kurds and Turks and Alevis and Sunnis, for which they wrote more songs about peace and reconciliation than have their Sunni Muslim musician friends.

\section{Conclusion}

In this article, I have analyzed the music produced for and consumed by the Kurdish Alevis in Cologne and Istanbul who trace their first homeland to the cities of Maraş, Malatya, and Adıyaman in Kurdistan or Eastern Turkey. I have aimed to shed light on how a group of people within a predominantly Sunni Muslim majority in Turkey and a white nativist majority in Germany relies on music to navigate and negotiate religious constraints and secular contempt in Turkey, and with a secular German context in which they were granted religious and cultural rights. In the discussion of culture, politics, and religion in the lives of this immigrant community, I have approached Kurdish Alevi discourses of belonging through music as an embodiment of all three at once. Kurdish Alevis have engaged with the politics of recognition through multiple identities that at times contradict each other. The contradictions grew as they moved from one homeland to the next. The meanings and contradictions exist not only in terms of political realignments but also in issues of representation of identities.

Until the establishment of the transnational space among immigrants in Turkey and Germany, the Turkish ideological state apparatus controlled the dissemination of particular forms of cultural production in the public sphere. Politically active musicians and artists have created alternative and protest voices, challenging the hegemony of the Republic of Turkey and to a lesser degree the German federal government. Alongside state actors emerged religious, cultural, and hometown organizations that have been maintaining and benefiting from the new transnational social field. The immigrants and refugees in Germany and internal immigrants within Turkey established a new transnational social field.

Kurdish Alevis or Alevi Kurds have usually been in the minority of the aligned ideological, religious, and ethnic configurations of the Republic of Turkey as well as among the immigrant populations from Turkey in Germany. The music Kurdish Alevis have been listening to encompasses both the Kurdish and Turkish musical worlds as well as its unique traditional music developed in liminal space. The music that Kurdish Alevis have been creating and consuming has reflected sensibilities of all parties involved while providing a space for critique, resistance, and other longings. Displaced from their place of origin, many Alevi Kurds root themselves in a series of new homelands (Cologne and Istanbul, for instance), ally themselves with other Kurdish Alevis; and work to shore up and perpetuate the ties that bind all together regardless of the geographical distances separating them. 
Aksoy, O.

\section{References}

Abe, M. (2016). "Sounding against nuclear power in post-3.11 Japan: Resonances of silence and Chindon-ya". Ethnomusicology, 60 (2), 233-262. DOI:10.5406/ethnomusicology.60.2.0233

Aksoy, O. E. (2014). The music and multiple identities of Kurdish Alevis from Turkey in Germany. PhD Dissertation, City University of New York.

Ammann, B. (2001). Kurden in Europa: Ethnizität und diaspora. Münster: Lit.

Andrews, P., \& Benninghaus, R. (1989). Ethnic groups in the Republic of Turkey. Wiesbaden: L. Reichert.

Axel, B. (2001). The nation's tortured body: Violence, representation, and the formation of a Sikh "diaspora. "Durham: Duke University Press.

Ayata, B. (2011). The Politics of Displacement, A Transnational Analysis of the Forced Migration of Kurds in Turkey and Europe. PhD Dissertation, Johns Hopkins University.

Bayrak, M. (2011). Bir siyasettarzı olarak Alevi katliamlarl. Ankara: Öz-Ge.

Bohlman, P. (2004). The music of European nationalism, cultural identity and modern history. Santa Barbara, CA: ABC-CLIO.

Brinner, B. (2009). Playing across a divide: Israeli-Palestinian musical encounters. New York: Oxford University Press.

Bryant, R. (2005). Improvising in and through music-The soul danced into the body: Nation and improvisation in Istanbul. American Ethnologist, 32(2), 222-238. DOI: 10.1525/ae.2005.32.2.222

Clifford, J. (1997). Routes: Travel and translation in the late twentieth century. Cambridge: Harvard University Press.

Dressler, M. (2013). Writing religion: The making of Turkish Alevi Islam. New York: Oxford University Press.

Dressler, M. (2008). 'Alevis.' Encyclopedia of Islam (3rd ed.), 93-121. Leiden: Brill.

Ertan, M. (2008). The circuitous politicization of Alevism: Affiliation between the Alevis and the left politics (1960-80) (Masters thesis). Atatürk Institute Boğaziçi University, Istanbul.

Fitzgerald, J. (2019). Peace Up, A-town Down: Exploring the Evolution of Popular Music. American Journal of Qualitative Research, 3(1), 72-92. https://doi.org/10.29333/ajqr/5812

Gökalp, A. (1980). Têtes rouges et bouches noires: Une confrérie tribale de l'ouest Anatolien. Paris: Société d'Ethnographie.

Hirschkind, C. (2006). The ethical soundscape: Cassette sermons and Islamic counterpublics. New York: Columbia University Press.

Hong, G. (2006). The ruptures of American capital: Women of Color, feminism and the culture of immigrant labor. Minneapolis: University of Minnesota Press. Retrieved from http://public.eblib.com/choice/publicfullrecord.aspx? $\mathrm{p}=310747$.

Hyder, R. (2004). Brimful of Asia: Negotiating ethnicity on the UK music scene. Aldershot: Ashgate.

Kaya, Y. (2015). The Opinions of Primary School, Turkish Language and Social Science Teachers regarding Education in the Mother Tongue (Kurdish). Journal of Ethnic and Cultural Studies, 2(2), 33-46.

Kaya, M. (2011). The Zaza Kurds of Turkey: A Middle Eastern minority in a globalised society (Vol. 71). London; New York: I. B. Tauris.

Laurence, F., \& Urbain, O. (2011). Music and solidarity: Questions of universality, consciousness, and connection. New Brunswick, NJ: Transaction Publishers.

Lowe, L. (2007). Immigrant acts: On Asian American cultural politics. Durham: Duke University Press.

McDonald, D. (January 01, 2010). Geographies of the Body: Music, Violence and Manhood in Palestine. Ethnomusicology Forum, 19, 2, 191-214. DOI: 10.1080/17411912.2010.507463

Mackey, N. (1993). Discrepant engagement: Dissonance, cross-culturality, and experimental writing. Cambridge: Cambridge University Press.

Mahmod, J. (2016). Kurdish diaspora online: From imagined community to managing communities. New York: Palgrave Macmillan.

Manabe, N. (2015). The revolution will not be televised: Protest music after Fukushima.

New York, NY: Oxford University Press.

Massicard, E. (2013). The Alevis in Turkey and Europe: Identity and managing territorial diversity. London: Routledge.

Meintjes, L. (2003). Sound of Africa!: Making music Zulu in a South African studio. Durham: Duke University Press.

Nooshin, L. (Ed.). (2009). Music and the play of power in the Middle East, North Africa and Central Asia. London: Ashgate Press.

O'Connell, J., \& Castelo-Branco, S. E. (2010). Music and conflict. Urbana: University of Illinois Press.

Özyürek, E. (Ed.). (2001). Türkiye'nin toplumsal hafızası: Hatırladıklarlyla ve unuttuklarıyla. İstanbul: İletişim. 
Shannon, J. (2006). Among the Jasmine trees: Music and modernity in contemporary Syria. Middletown: Wesleyan University Press.

Sirkeci, I. (2006). The environment of insecurity in Turkey and the emigration of Turkish Kurds to Germany. Lewiston: E. Mellen Press.

Solomon, T. (2011). "Hardcore Muslims: Islamic themes in Turkish rap between diaspora and homeland." In K. van Nieuwkerk (Ed.), Muslim rap, Halal soaps, and revolutionary theater: Artistic developments in the Muslim world (pp. 27-54). Austin: University of Texas Press.

Sökefeld, M. (2008). Struggling for recognition: The Alevi movement in Germany and in transnational space. New York: Berghahn Books.

Spivak, G. (1993). Outside in the Teaching Machine. New York: Routledge.

Stokes, M. (2010). The republic of love cultural intimacy in Turkish popular music. Chicago: University of Chicago Press.

Sugarman, J. (1999). Imagining the homeland: Poetry, songs, and the discourses of Albanian nationalism. Ethnomusicology, 43(3), 419-458. doi:10.2307/852556

Thangaraj, S. (2015). Desi hoop dreams pickup basketball and the making of Asian American masculinity. New York: NYU Press.

Tolba, N. (2018). From Rebellion to Riots. Research in Social Sciences and Technology, 3(2), 93-114. Retrieved from http://ressat.org/index.php/ressat/article/view/358

Turino, T. (2008). Music as social life: The politics of participation. Chicago: University of Chicago Press.

Urbain, O. (2008). Music and conflict transformation: Harmonies and dissonances in geopolitics. London; New York: I. B. Tauris.

van Bruinessen, M. (1997). "Aslini inkar eden haramzadedir!" The debate on the ethnic identity of the Kurdish Alevis. In K. Kehl-Bodrogi, B. Kellner-Heinkele, \& A. Otter-Beaujean (Eds.), Syncretistic religious communities in the near east (pp.1-23). Leiden: Brill.

Zürcher, E. (2004). Turkey A Modern History. London: I.B. Tauris.

\section{Discography}

Ahmet Aslan. Veyhê Milaketu. Kalan Müzik. 2007: Turkey

Ahmet Kaya. Ağlama Bebeğim. Gam Müzik. 1985: Turkey.

Ali Baran. Teberîk. Baran Production. 2005: Germany and Turkey.

Ali Baran. Ey Dersimê. 1987.

Ali Baran. Deriye Hepisxane. 1984

Bese Aslan. Ocax û Xwelî-Zêmarên Kurden Elêwî [Hearth and Ash- Kurdish Alevi Laments]. Kalan Müzik. 2011:

Turkey

Cemil Koçgün. Heya. Kalan Müzik: 2007. Istanbul.

Ciwan Haco. Dûrî. Ses Plak. 1994: Turkey.

Ciwan Haco. Bilûra Min. Kom Müzik. 1997: Turkey.

Delil Dilanar. Zerîyê. MIR Multimedia. 2009: Germany.

Dertli Divani. Düvaz İmam. Güvercin Müzik. 2008: Turkey.

Grup Kızılmark. Çı̆̆lık. Son Müzik. 1994: Turkey.

Grup Yorum. Cemo / Gün Gelir. Kalan Müzik. 1989: Turkey.

Kıvırcık Ali. Isırgan Otu. İber Müzik. 2001: Turkey.

Kızılbaş. Kalan Müzik. 2009: Turkey

Metin\&Kemal Kahraman. Deniz Koydum Adını. Hades. 1993: Turkey.

Metin\&Kemal Kahraman. Çevere Hazaru. Lizge. Turkey

Mikail Aslan. ZerNkut. Kalan Müzik. 2008: Turkey.

Mikail Aslan. Agerayîs. KOM Müzik. 2000: Turkey.

Nizamettin Arıç. Dayê. Ses Plak. 1987: Turkey.

Ozan Garip Dost. Ori Mazin-Mamko. Özdiyar Müzik Yapım. 2009: Turkey.

Pirler Divanı -Dîvane Pîran, Sinemilli Yöresinden Deyişler. KOM Müzik. 2008: Turkey.

Shêxo. Denge Avê. Ses Plak. 2009: Turkey.

Shêxo. Li Ezmanan Hezkirin. Ses Plak: 2005: Turkey.

Tahtacılar. Kalan Müzik. 1997: Turkey.

Ulaş Özdemir. Bu Dem. Kalan Müzik CD 453. 2008: Turkey. 